\title{
The Properly Improper: Making Sense of Humanity through Derrida, Butler and
}

\section{Rosaldo}

\author{
Manali Arora, Master's Student, Ambedkar University Delhi, India \\ Email: manaliarora487@gmail.com
}

\begin{abstract}
That which is proper to humans or which makes a human proper- of which hundreds have been conceptualized- consists of ethics, moral values, expression, responsibilities at the nexus of society, culture, individual differences. As these conceptualizations are closely scrutinized, the universality of a proper being begins to disintegrate, binaries emerge along with the ethical questions to which the answers are not easily found.

In this paper, beginning with the religious theorization of what is a proper human, making sense of it through Kafka's Metamorphosis and elucidating on the aspects of humans like Gaze, Animality, and Rage that puts propriety into question, ethical questions are raised which are suggestive of human ignorance towards the obvious.

Abstracting from the works of Jacques Derrida, Renato Rosaldo, and Judith Butler, this paper attempts to answer the question of what is being a proper human by examining the culture, contexts, and contemporary intersectionality, leaving a few questions open to the readers.
\end{abstract}

Keywords: Gaze, Animality, Rage, Hierarchy

\section{INTRODUCTION}

"Human existence basically is a never to be completed imperfect tense." 
In Hindu mythology, a proper human is the one who seeks to pursue, in their brief life span, Purusharthas, i.e., to achieve the four-fold meaning/purpose of life: Righteousness (Dharma) which requires one to be moral, ethical and assume responsibility; Wealth (Artha) which mentions the pursuit of prosperity, Desire (Kama) which can be defined as obtaining enjoyment from life, and most importantly Salvation (Moksha) which is the most challenging meaning to achieve- the enlightenment (Sivakumar, 2014).

These ideas that Hinduism professes are inscribed into the minds of the majority of the Indian population, as Hinduism is the largest religion in the country (Office of the Registrar General \& Census Commissioner, India, 2001). However, as one moves on from here, these ideas of what it means to be a proper human, begin to, if not entirely disintegrate, become questionable. The Metamorphosis, a novel by Kafka, is a story of a salesman named Gregor who, one morning, finds himself inexplicably turned into a giant insect. On realizing that his transformation into a vermin is a reality and not just a dream, he instead is worried about being late for work, contemplating about his aging parents not being well enough to earn for themselves and his plan to send his sister to a music conservatory for which he has been saving up (Dharma- Responsibility). Being the only breadwinner of the family, he worked tirelessly to earn enough to also be able to pay off his bankrupt father's debts (Artha- Pursuit of prosperity). Accepting his transformation, he tries to adjust to the struggles of his new way of being. He would spend most of his time crawling around his room when one day, his mother finds him clinging to a picture of a lady on the wall and faints. This picture that Gregor had lovingly framed symbolized his former status as a human with sexual urges (Kama- Desire). Seeing his wife faint, Gregor's father angrily hurled apples at him, one of which became lodged in a sensitive spot of his back and gravely wounded him. Injured and deeply distressed at the knowledge of his family's neglect towards him and him not being wanted, finding life to be meaningless (Moksh- Enlightenment), Gregor Samsa died of starvation (Kafka, 2018) 
Taking The Metamorphosis as a reference and drawing parallels to the meaning of life according to the Purusharthas, the pursuit of which makes one a proper human, is to show how Gregor Samsa, in being turned into a vermin, suddenly became devoid of the right of being proper or even a human. He could no longer fulfill his responsibility, acquire wealth, obtain enjoyment or attain enlightenment on his being turned into a vermin. This is to further say that a human, owning the ability to pursue these meanings, stands the inevitable capability of being proper, and everything else that doesn't have the ability to pursue the same, to be proper, is automatically labeled improper. Reaching this conclusion comes with an apparent hierarchy: proper and improper, and with this binary, comes the privilege that one term has over its opposite (Prasad, 2010). The question then emerges is that, is a proper human the one who has the power over, and superior to the improper other (here the vermin) which has now been coerced to carry the label of improper, enforced by the humans on the basis of their ideals of being proper, a self-fulfilling prophecy? Does taking birth as a human among the innumerable species of life (the other) in the strenuous journey through countless births (Hindu, 2013) is itself a blessing like the Hindu Mythology claims?

This paper attempts to 'raise' these questions, questioning the 'propriety' of humans through engaging with gaze, animality, rage, and hierarchies, not to answer them with certitude, as it would again mean falling into the trap of absolute knowability but to question the illusion of certitude humans tend to live with. The disillusionment caused by engaging with Derrida (2009), Rosaldo (1993) and, Butler (2014) (in following three section) will raise more questions out of many others that plague humankind, suggesting the unknown and unknowable as the outer limits of human possibilities.

\section{Humanity- Animality}

Jacques Derrida in 'The Animal that Therefore I am, 'a translation of his ten-hour address to the 1997 Crisy conference, calls into question this a priori knowledge that humans use to 
conceptualize the animal as other and alerts us to the idea that though we often think of 'other,' human identity, in fact, rests upon the animal nature; that human may actually be also behind, subordinate, subject to the animal. Caught naked in front of his cat, he feels embarrassed and astonished to find that the gaze of an animal has successfully made him feel shame, not for being naked per se but for being ashamed. He is ashamed of being ashamed because he realizes that he should not be ashamed in the first place, that in the first place, he is ashamed of being an animal, i.e., naked, and ashamed of being ashamed because humans are animals and shouldn't be ashamed for being so. It isn't just the body that is revealed in front of the cat, but also his nakedness which stands in for the truth revealed about the humans, that humans usually try to hide that they are animals. Biting his tongue as if holding back something that is forbidden, in a brute and physical response, an unthinking, asinine reaction to a problem that should have been faced with intelligence and rationality (these being the qualities 'reserved' for humans) we are made, in some sense an animal by our embarrassment and reflex to hide that embarrassment, but it is only the human who is embarrassed by its nakedness. Animals would not be in truth naked because they are already naked, naked without existing in nakedness. Clothing is only proper to man, it being inseparable from all the other forms of what is proper to humans. Humans would be the only ones to have invented a garment to cover their sex and would only be a human to the extent they are able to be naked, that is to say, to be ashamed. Animals, being unaware of their nudity, exist in a state of non-nudity; meanwhile, humans who are nude are never nude because they are ashamed and are constantly hiding or clothing at least in their minds who or what they truly are, thus never truly being naked. So, in our embarrassment, when we are mentally unclothed, and our animalness is revealed, are we or are we not nude? (Derrida et.al., 2009).

\section{To see or be seen}


Derrida does not give a clear answer to this but to the question: what are we ashamed of, he concluded that it is our own animality. To the question of naked before who, Derrida drew our attention to the cat's gaze, which was in nature aggressive, active. A gaze, being an aggressive gesture, takes me to Sartre's conception of the gaze as it being the battleground for the self to be defined and redefined; one becomes aware of the self as subject only when confronted with the gaze of the Other and become aware of the self as an object (University of York 1994), like how Derrida's cat's gaze reverses the usual relationship we think of as existing between the animals and humans, or master or slaves as Hegel would put it. Foucault gave almost a paranoid idea of the gaze, claiming the gaze to be the perfect medium for extending domination and in this disembodied gaze, power becomes manifest and permeates to even the minuscule elements of life, "perpetuating itself not through external force but through internal penetration" (Reinhardt, 2021), in this context, stripping us to our own animality.

Purporting to speak for or protect the animal without ever really taking a moment to be seen by an animal, asking if animals can suffer (Jeremy Bentham's defense of animal rights), depriving them a chance to name themselves by naming them and thus assuming sovereignty and power, defining the non-human with the inability to speak, calling Gregor Samsa 'it' that needs to be get rid of on being turned into a vermin, professing the ideals of being a proper human (Purusharthas), as animals 'must' having to have sex in order to survive (devoid of Kama), and them being devoid of Dharma (Without Dharma, humans are the same as animals says- Hitopadesha Verse 24) are simply many ways of othering. The aim is not to pity and protect the non-human, not even change the way we look at them but in the way we think about them (for that he gives the term 'Animot' which recognizes plurality of animals and ourselves as reflected in animals, overcoming our preconceptions of the binary), get looked at by them, expose ourselves, make ourselves vulnerable to being objectified by their subjective gaze. It is probably why it is easier for humans to kill an insect and not an animal and even less another 
human because it is difficult to see an insect seeing us; after all, their gaze cannot be comprehended as directed towards us. Thus, when we look at each other in a way, becoming vulnerable to the other's gaze, that the preconceived binary of human and non-human gets blurred, in a way one no longer knows who is the seeing and who is the seen, like two mirrors being placed in front of each other (Ponty et al., 2013), that we realize, to answer Derrida's question of who we are following, that we are following ourselves.

However, the alternative dilemma then arises is that how do one then engages with non-human animals in a way that their subjectivity is not projected onto them. Maybe, asking this question in itself is a projection. Where does one place other species such as a vermin in the question of othering, and how do one surmount the hierarchy imprint in our minds where beings are identified as 'easily killable,' (species other than animals) 'killable' (animals), and 'not at all easily killable' (humans). Or is it even possible to overcome such a hierarchy because, as Levinas says, "only humans can properly die (and thus must not be killed); only a human has a naked face that reveals "his" vulnerability and calls me to respond to it, to be responsible to or for it" (Weil, 2008). Shown in "Men against Fire," the fifth and penultimate episode of the third series of British science fiction anthology series Black Mirror, a neural implant called MASS was inserted in soldiers that provided data via augmented reality. In that, soldiers could not see the face of the victim and hear only incomprehensible shrieks, which made it easier for them to kill another human without hesitation or remorse (Brooker, 2016). As Levinas (1995) says, "The face is what forbids us to kill."

Nonetheless, if nothing at all, the gaze enables one to address the vulnerabilities we all share as living, breathing beings; it allows one to acknowledge the realities of the being of the other as unbeknownst to us, despite our attempts to name it (Weil, 2008). And probably the answer to the question of how to then engage with the animals, non-humans and the likelihood of overcoming hierarchy lies in Derrida's assertion of letting animals be in their being, outside our 
projects and our will for knowledge, which would constitute the ultimate ethical stance (Weil, 2008) because even humans very likely don't know the world as such and in a manner different from animals who, Heidegger argues, are believed to see the world only in regards to utility, led by drives or desires (Calarco, 2008). The bigger question now is, for what purpose do we construe differences?

\section{An emotion improper?}

Continuing from Jeremy Bentham's impassioned plea against animal maltreatment, his question, "Can animals suffer," opens the door to doubt about whether or not they can suffer; the repercussions of that is that an othering effect is fabricated, manifesting in brutality against animals. This conceptualization of suffering that generates the othering effect attempts to sketch what is proper to a human and what is not. The question that comes up is that, is a proper human the one that Freud talks about, the one who attempts to modify an inevitability of being i.e., suffering and divert an instinctual impulse like rage into a culturally higher or socially more acceptable activity (sublimation) or the one who in the process of diverting rage or modifying suffering, makes other people suffer (the headhunting practice). Can the question, “Can those people suffer?" will then be asked.

Renato Rosaldo, in the book Culture \& Truth: The Remaking of Social Analysis, elucidates on the headhunting practice among the Ilongots of Northern Luzon, Philippines. The victims of the headhunting at various periods were fellow Ilongots, lowland Christian Filipinos, and Japanese soldiers. The whole act of headhunting that took place as a surprise attack, planned vendetta, or distant raid against strangers, as Rosaldo (1993) puts it, was in response to the rage emerging from the grief, grief of a "relation's permanent rupture."

The need to sever and toss away the victim's head to vent and throw away the anger of their bereavement is in contrast to the need of proper humans to dissociate from rage, as Derrida et al. (2013) say, as rage is believed to take humans away from the so-called civilization, 
'inhabitance of the propers.' In such an assertion, again is formed an othering effect of those, whose form of expression of grief would not only seem alien but also 'immoral.' However, to think about what morality is, is it that which Immanuel Kant's philosophy attempts to ground: it being based on a single supreme universal principle, which is obligatory to all 'rational beings' (Bennett, 2017) or is morality based on that which is declared legal by those very rational beings, and is nothing more than a 'legal-normative aphorism.' It is to think about if this practice would still be considered improper to humans if Ilongots had the socio-political power to make this practice widespread and commonplace. Is it safe to say that it is more the social sanction than the question of morality that enables the vehemence of emotional expression, that it is the social sanction that allows sobbing uncontrollably, punching on a wall to become a matter of concern and empathy, and tossing off someone's head in response to loss, a subject of judgement? Nevertheless, for those the practice of headhunting as a modus operandi of casting away the rage underlying grief raises a moral question, as it involves the annihilation of the other and defies the notion of a proper human, where would then morality be placed in the contemporary world where the 'proper beings' are prompted to progress at the expense of the other, psychical annihilation of a kind. Bringing someone down to achieve an end then becomes as much a part of this culture as it does of Ilongots. How does psychical killing not raise a moral question as killing in a non-metaphorical sense does? And if it doesn't raise as grave a moral question as does an actual killing, where do we place wars in the frame of morality, in which not just one in place of another is killed, but innumerable deaths constitute the phenomenon. Freud (1922), in the wake of World War I, musing on the psychological responses to loss, wrote a paper called Mourning and Melancholia, in which he defines mourning as "a reaction to the loss of a loved person, or the loss of some abstraction which has taken the place of one, such as one's country, liberty, an ideal and so on." It is this unbearable grief, and its unbearability that impels one to kill, causing more suffering, (Butler, 2004) a 
double-whammy of some sort. How is then the mourning of an Ilongot who has lost a loved person different from that of a soldier who has lost an ideal, impelling both to kill?

This uncanny transition, says Butler (2004), from unbearable grief to uncontrollable rage and destructiveness, is perhaps "a way of announcing that what is unbearable is now someone else's problem," maybe the wager is that this 'I' in destroying suddenly becomes pure action, an embodiment of rage and of transferring it, finally rid of passivity. Like how it is through someone's gaze, aggressive in nature (Derrida et al., 2009) that one feels alienated and objected (Sartre, 2001), it is in someone else's presence that one can express rage, 'a furious form of grief.' Butler (2004) asks if it is possible to find a source of non-violence in this unbearable grief, stay with the unbearable loss without converting it into a wreckage, and find another way of living with it that is not the same as bearing it. She adds that "even before losing, we are lost in the other, lost without the other but not knowing it before we actually lose." We already are at the hands of the other, "we are from the start both done and undone by the other, and if we refuse this, we refuse passion, life and loss. The lived form of that refusal is destruction and the lived form of its affirmation is non-violence" (Butler, 2004). Thinking about loss, are we, as humans, ever really without loss, hence grief. Do we or can we ever stop mourning? Aren't we always at a loss of something because it's not just the actual loss of something that creates the experience of a loss, but a knowledge of what it would be like to have something also creates a similar experience of loss? As Derrida too suggested that to be human, there is a fundamental loss, a fundamental abjection, a loss that can never be mourned entirely (Englebert, 2011).

At last, the subjective experience of loss and numerous other differences nonetheless exist in ways of beings, in one's culture, species, modes of expression and will continue to do so. The idea is not to overcome the differences, but like the idea of 'animot,' it is to be pluralized, call attention to the many differences, as these are also the differences that the humans, in 
themselves harbor, differences from the names with which we call themselves, from the human-animal we think we are (Weil, 2008). So, what is being a proper human? It perhaps is being, being in the world, not being as against the animal, proper as opposed to the improper, civilized opposite the primitive, being the one to judge the judged but being. A proper human is the being, being with other beings, with other forms of being, and with the many ways of being, transcending the binaries, the properly improper. 


\section{REFERENCES}

(2014) Judith Butler: Speaking of Rage and Grief. (2014, April 29). [Video]. YouTube. https://www.youtube.com/watch?v=ZxyabzopQi8\&t=589s.

Bennett, J. (2017). Groundwork for the metaphysics of morals. Oxford University Press.

Brooker, C. (Writer) Verbruggen, J. (Director). (2016, October 21). Men Against Fire (Season 3, Episode 5) [TV series episode]. In A. Jones, C. Brooker (Executive Producers), Black Mirror. House of Tomorrow.

Calarco, M. (2008). Zoographies: The Question of the Animal from Heidegger to Derrida. Columbia University Press.

Derrida, J., Mallet, M.L., \& Wills, D. (2009). The Animal That Therefore I Am. Amsterdam University Press.

Eengelbert, L. (2011). "Wild" Freudian Psycho-Analysis: Ingestion, Incorporation, and Mourning in Derrida and Deleuze and Guattari. Mosaic: An Interdisciplinary Critical Journal, 44(4), 161-176. Retrieved August 25, 2021, from http://www.jstor.org/stable/44029574.

Freud, S. (1922). Mourning and Melancholia. The Journal of Nervous and Mental Disease, 56(5), 543-545.https://doi.org/10.1097/00005053-192211000-00066.

Hindu, T. (2013, November 5). Invaluable human birth. The Hindu. https://www.thehindu.com/features/friday-review/religion/invaluable-humanbirth/article5314444.ece.

Kafka, F. (2018). The Metamorphosis. CreateSpace Independent Publishing Platform.

Levinas, E., \& Cohen, R. A. (1995). Ethics and Infinity: Conversations with Philippe Nemo (1st ed.). XanEdu Publishing, Inc. 
Merleau-Ponty, M., Landes, D., \& Carman, T. (2013). Phenomenology of Perception (1st ed.). Routledge. (Originally published 1945)

Office of the Registrar General \& Census Commissioner, India. (2001). Census of India: Religion. https://censusindia.gov.in/census_and_you/religion.aspx

Prasad, J. (2010, December 10). 3. Some Key Terms. Derrida: The Father of Deconstruction. https://newderrida.wordpress.com/2007/11/19/some-key-terms/.

Reinhardt, J. (2021). gaze | The Chicago School of Media Theory. The Chicago School of Media Theory. https://lucian.uchicago.edu/blogs/mediatheory/keywords/gaze/.

Rosaldo, R. (1993). Culture \& Truth: The Remaking of Social Analysis. Beacon Press.

Sartre, J. (2021). Being And Nothingness (Paperback edition). Routledge.

Sivakumar, A. (2014, October 12). The Meaning of Life According to Hinduism Philosophy 1100H Blog. Philosophy 1100H Blog. https://u.osu.edu/group5/2014/10/12/themeaning-of-life-according-to-hinduism/comment-page-1/.

University of York. (1994, April). The Gaze In Theory: The Cases Of Sartre And Lacan (Thesis). Melinda Jill Storr. https://etheses.whiterose.ac.uk/2527/1/DX180654.pdf.

Weil, K. (2008, October). Weil on Derrida, “The Animal That Therefore I Am” | H-Animal | H-Net. Humanities and Social Sciences Online. https://networks.hnet.org/node/16560/reviews/16726/weil-derrida-animal-therefore-i-am. 